v. $7, n .1$

Vitória-ES, Jan - Apr.2010

p.59-88 ISSN 1808-2386

DOI: http://dx.doi.org/10.15728/bbr.2010.7.1.4

\title{
Payroll loans by old age and survivors pensioners: an exploratory study using the principles of actuarial mathematics
}

\author{
Fernando Henrique Câmara Gouveia ${ }^{\dagger}$ \\ University of São Paulo \\ Luís Eduardo Afonso ${ }^{\square}$ \\ University of São Paulo
}

\begin{abstract}
Credit activity has been growing strongly in Brazil since 2004. An important factor is personal loans to people receiving benefits from the Brazilian National Social Security Institute (INSS) with repayment by automatic deduction from their benefits. This paper investigates whether the rate of return obtained by financial institutions on these loans is the same as that on personal loans to salaried workers with automatic payroll deduction. The method to calculate these rates includes use of the actuarial mathematics' principles, through the incorporation of a biometric risk factor associated with the borrower's age. Employing a sample of 23 financial institutions, we compare the difference in the rates of return after considering the default costs, which are influenced by borrowers' characteristics of two groups. The first group, composed of pensioners (both retirees and people receiving survivor pensions), is the treatment group. The control group is made up of São Paulo Municipal Government employees. The results provide significant evidence that, for the sample studied, the return obtained by financial institutions is greater on loans to social security beneficiaries.
\end{abstract}

Keywords: Payroll loans, old age and survivors pensioners, biometric risk, actuarial mathematics, social security

Received in 07/15/2008; revised in 10/20/2009; accept in 12/07/2009

Corresponding Author *:

${ }^{\dagger}$ Bachelor's in Accounting Sciences from FEA/University

${ }^{\square}$ Ph.D. in Economics from FEA/University of São Paulo. of São Paulo.

Studying for a Master's in Control and Accounting at Professor in the Department of Accounting and Actuary of FEA/University of São Paulo.

FEA/University of São Paulo

Address: Avenida Luciano Gualberto, no. 903, FEA3, sala

215, São Paulo - SP - Brazil - CEP 05508-900.

Address: Avenida Luciano Gualberto, no. 903, FEA3, sala

215, São Paulo - SP - Brazil - CEP 05508-900.

E-mail: lafonso@usp.br

E-mail: fernandohcg@gmail.com

Telephone: (11) 3090-5820, extension 134

Telephone: (11) 3542-982

Editor's note: This paper was accepted by Antonio Lopo Martinez 


\section{INTRODUCTION}

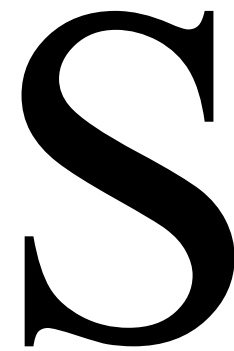

ince the end of 2004, Brazil has experienced strong growth (averaging $10 \%$ a year as a proportion of GDP) in the balance of free credit (as opposed to directed lending under government programs). Starting in 2006 there was a sharp reduction of the average interest rate on such credit transactions, which fell from 54\% a year in January 2006 to $44 \%$ in January 2008. These figures are shown in Graph $1^{\mathrm{i}}$.

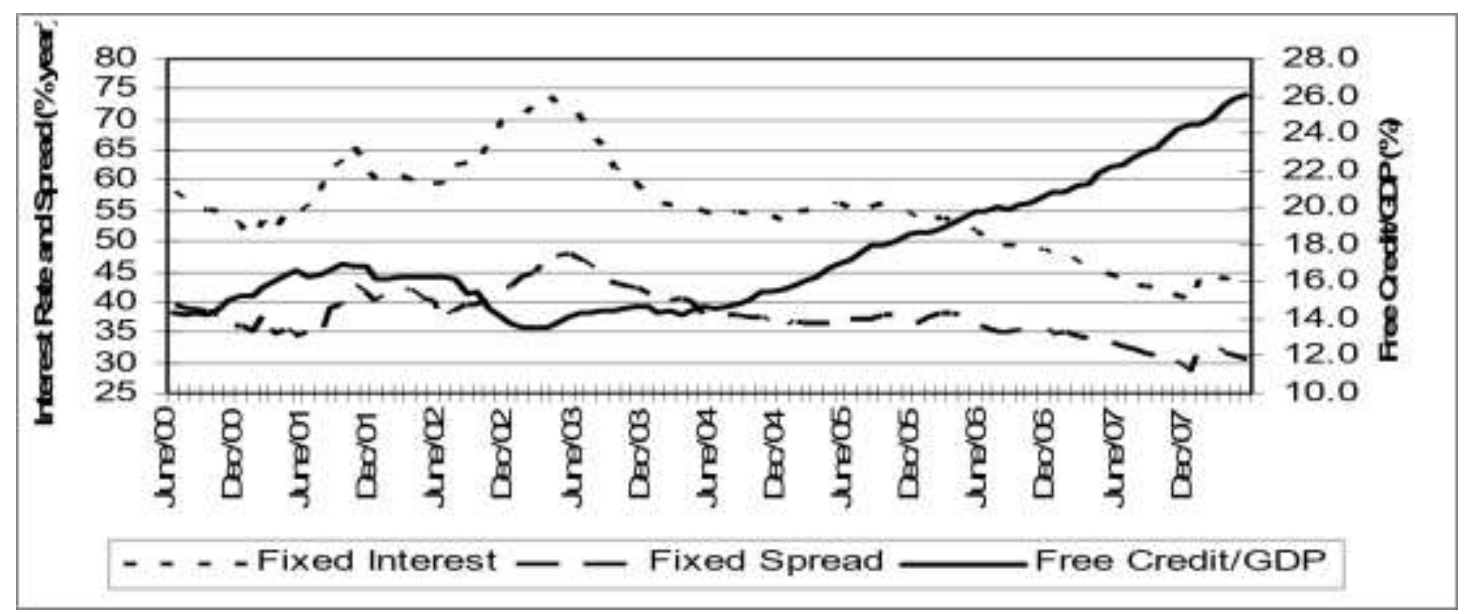

GRAPH 1: INTEREST RATE, SPREAD AND FREE CREDIT/GDP

Source: BCB (Time Series/Economic Department)

Graph $2^{\mathrm{ii}}$ shows that the increase in free credit included both personal and business loans. In December 2007 and May 2008 (last figure in the graph) the balance of personal loans was, respectively, $12 \%$ and $6 \%$ higher than that of business loans.

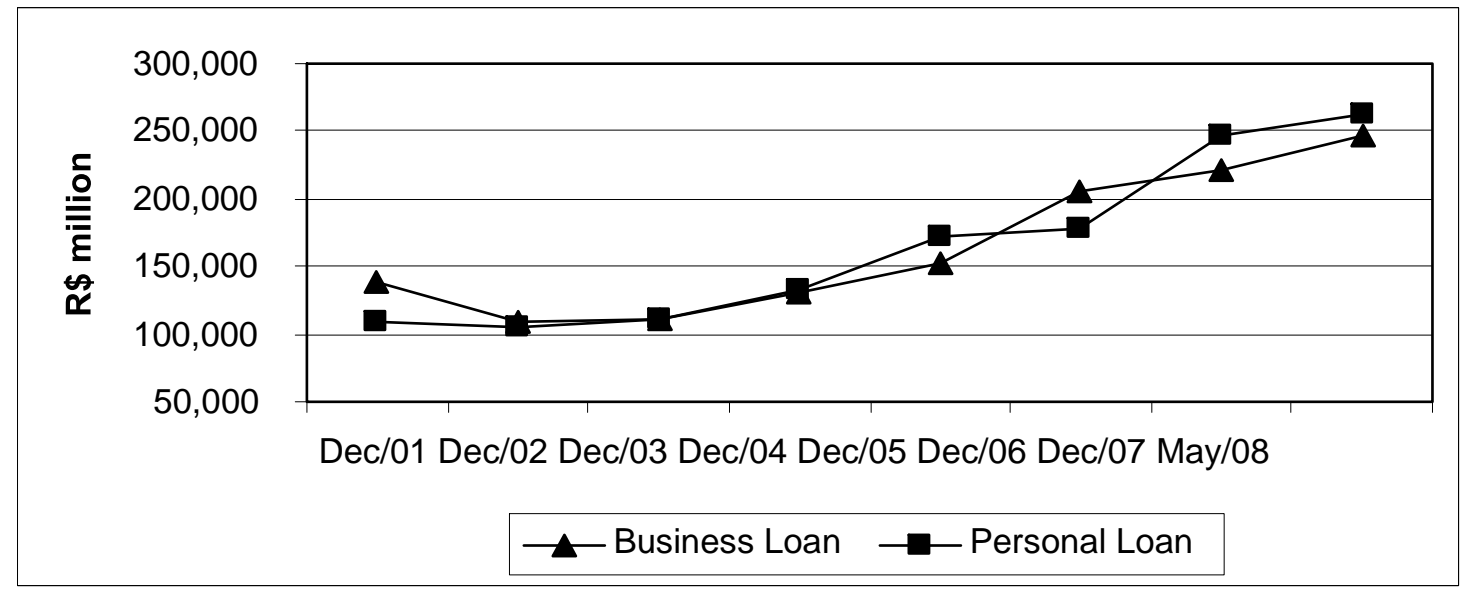

GRAPH 2: BALANCE OF DOMESTIC LENDING(CREDIT AT THE REFERENTIAL INTEREST RATE)

Source: BCB (2002, 2003, 2004, 2005, 2006, 2007 and Time Series/Economic Department)

Since October 1999 the Brazilian Government and the Brazilian Central Bank (BCB) have been acting together on a project to lower interest rates and the bank spread 
(called Projeto Juros e Spread Bancário, or PJSB), aiming to expand credit and reduce loan costs.

The main measures of the PJSB are in the institutional sphere, as part of the microeconomic agenda, undertaken by the Federal Government since 2003. In the view of the Central Bank, these actions are responsible for reducing the cost of credit in recent years.

Among these measures are: reduction of bank reserve requirements; improvement of the Brazilian Payment System; improvement of the Accounting Plan for Institutions of the National Financial System (COSIF); portability of banking history information (facilitating changing banks); more detailed disclosure to customers about the costs of overdraft checks; securitization of receivables; creation of the Bank Credit

Note; reform of bankruptcy legislation; simplified procedures to enforce judicial awards in the Civil Procedure Code; and expansion of the system of personal loans with repayment by automatic deduction from payroll or social security benefits (together called crédito consignado, or "payroll loans").

With respect to the last item, the payroll loans system dates back to 1990, but at that time it only entailed payroll loans to civil servants.

The extension of this system to workers in the private sector and people receiving social security benefits has been very important in increasing the supply of personal loans in Brazil.

Since social security beneficiaries became eligible for this type of credit, the National Social Security Institute (INSS) has been issuing regulations to limit the repayment periods, installment values and interest rates of these loans.

In this context, in this article we investigate whether the rate of return obtained by financial institutions on payroll loans to social security beneficiaries (henceforth called INSS payroll loans) is the same as that on payroll loans to salaried workers (henceforth called payroll loans).

Analysis of the factors composing the bank spread shows that default is the only observable cost factor that varies according to the observable characteristics of the borrower in the case of payroll deduction loans. 
In the case of INSS deduction loans, the default cost is basically associated with the risk of the borrower's death (biometric risk), since the automatic deduction from benefits prevents borrowers from defaulting.

To isolate the factors associated with biometric risk, it is necessary to employ concepts of treatment group and control group. In this article, the treatment group consists of social security beneficiaries (retirees and receivers of survivor benefits) who have taken out automatic debit loans.

Therefore, this paper from a theoretical perspective is aligned with the contributions on credit risk, focusing on the particular case of payroll loans (automatic debit loans) in Brazil and the relevance of biometric risk as an element affecting the interest rate charged.

The control group consists of civil servants working for the São Paulo Municipal Government (PMSP). The justification for choosing this group is that it has a set of observable characteristics similar to those of the treatment group.

The default risk of the two groups is similar, given the job stability enjoyed by civil servants, with the exception of the biometric factor, since the average age of the treatment group is higher.

To carry out the study we obtained data on the nominal interest rates charged on automatic debit loans to social security beneficiaries and PMSP civil servants. We gathered the data in the first half of June 2008 from 23 financial institutions.

We addressed the research question based on an index called the Rate of Return after Default Costs (RRADC).

We obtained this by calculating the internal rate of return and incorporating the biometric risk (based on the mortality table calculated by the Brazilian Institute of Geography and Statistics - IBGE - for 2006) and the processing fee charged by the PMSP for transferring the payroll deductions to the lender financial institutions.

We found that on average, the INSS deduction loans imply higher RRADCs than payroll deduction loans to São Paulo Municipal Government employees. In other words, within the sample of banks considered, it can be stated that the rate of return they obtain is higher on INSS deduction loans than on payroll deduction loans to municipal civil servants. 


\section{PAYROLL LOANS OPERATIONS}

\subsection{A brief history and evolution of payroll loans}

As part of the program to lower the interest rate and bank spread (PJSB), Law 10820 was enacted in 2003. It extended eligibility for payroll loans, which had existed since 1990 only for civil servants (Law 8112/1990), to private-sector workers and social security beneficiaries.

Payroll loans is one of the loan types available to individuals (also composed of overdraft checks, regular personal loans, mortgage loans, car loans, installment purchase of goods, credit card debt and others).

Graph 3 shows the evolution of the balance of personal loans (including all automatic debit loans), payroll deduction loans and INSS deduction loans. Takeda \& Bader (2005) indicate three important dates in the evolution of payroll loans.

The first was in December 2003, when Law 10820/2003 was enacted allowing the extension to the private sector of the existing payroll loans system applicable to civil servants.

The second was May 2004, with the start of actual operation of this system for social security (INSS) beneficiaries, from which point the growth of payroll loans was fairly stable until November 2004.

The third was in December 2004, when the growth of these automatic debit loans

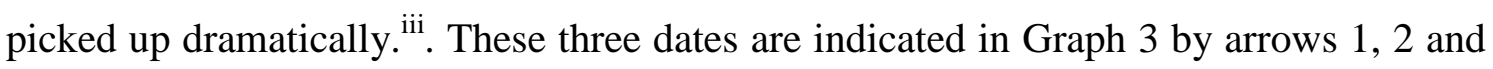
3.

As can be seen in Graph $3^{\text {iv }}$ and Table 1 (containing the data from which Graph 3 was plotted), the increase in the balances of personal loans was partly driven by the growth of INSS deduction loans.

Only in 2007, three years after the conclusion of agreements between the INSS and financial institutions to operationalize INSS deduction loans, did the level of these loans equal the overall level of personal credit (including INSS payroll loans). 


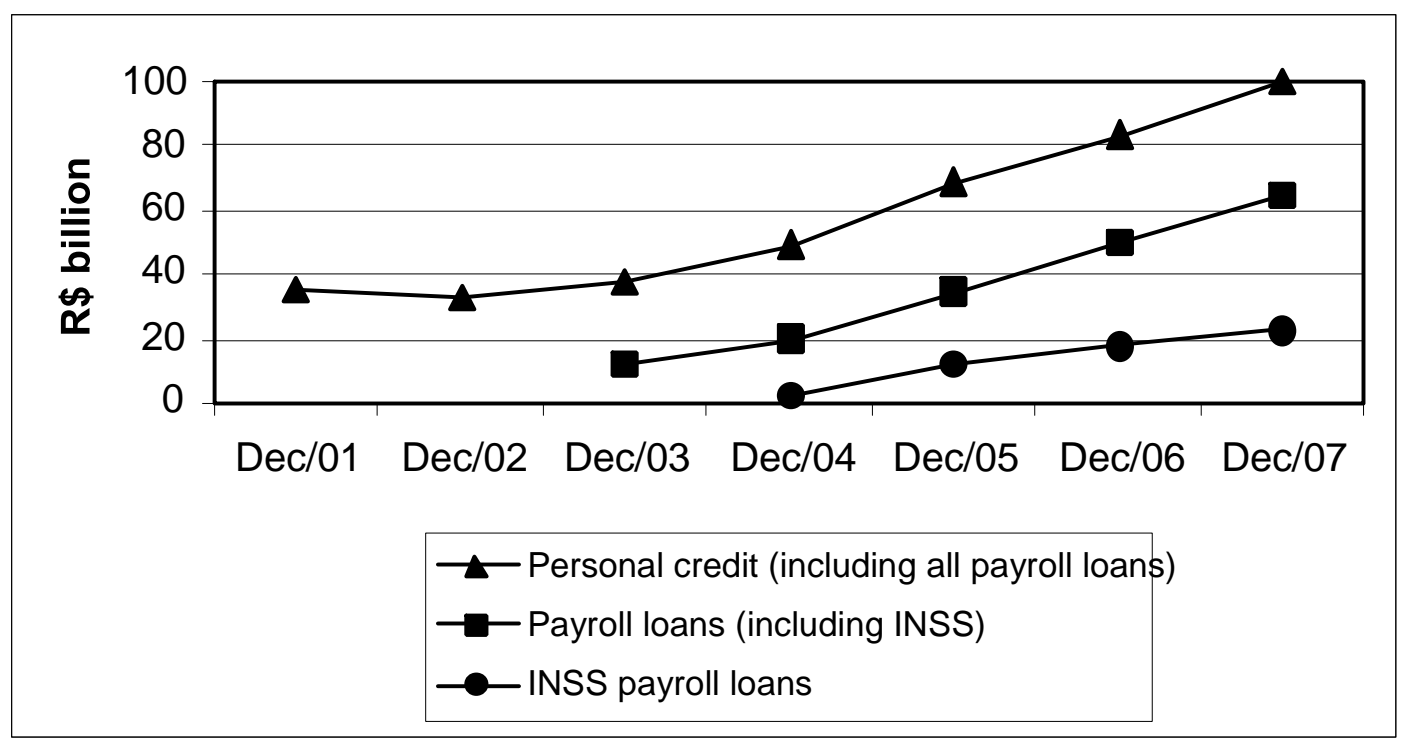

GRAPH 3: BALANCE OF CREDIT TRANSACTIONS - INDIVIDUALS (NOMINAL VALUES) Source: DATAPREV, BCB (2002, 2003, 2004, 2005, 2006, 2007 and Time Series/DEPEC)

In December 2005 INSS deduction loans represented 34\% of all automatic debit loans, and in December 2007 this figure was 35\%.

Table 1: Annual variation of credit transaction balances - individuals (\%)

\begin{tabular}{|c|c|c|c|c|c|c|}
\hline & Period & & & & & \\
\hline & $\begin{array}{l}\text { Dec/01 } \\
\text { Dec/02 }\end{array}$ & $-\begin{array}{l}\text { Dec/02 } \\
\text { Dec/03 }\end{array}$ & $-\mid \begin{array}{l}\text { Dec/03 } \\
\text { Dec/04 }\end{array}$ & $-\mid \begin{array}{l}\text { Dec/04 } \\
\text { Dec/05 }\end{array}$ & $\begin{array}{l}\text { Dec/05 } \\
\text { Dec/06 }\end{array}$ & 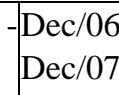 \\
\hline $\begin{array}{l}\text { Personal Credit (including all payroll } \\
\text { loans) }\end{array}$ & -6.16 & 13.90 & 32.24 & 38.22 & 22.19 & 19.94 \\
\hline Payroll Loans (including INSS) & & & 64.80 & 74.38 & 47.12 & 28.77 \\
\hline INSS Payroll Loans & & & & 415.66 & 51.22 & 27.27 \\
\hline
\end{tabular}

Source: DATAPREV, BCB (interest rate and bank spread from 2002 to 2006), BCB Bulletin, Dec. 2007, Economic Department

Graph 4 below presents the evolution of the number of loans and loan balances of INSS deduction loans. In slightly over two years the number of loans doubled and the volume of funds lent nearly tripled.

\subsection{Inss payroll loans rules}

Only financial institutions that have agreements with the INSS can offer this type of payroll loans.

The conditions under which retirees and receivers of survivor benefits can take out these loans are regulated by the INSS by the issuance of normative instructions 
(instruções normativas). Table 2 shows the main rules for INSS deduction loans in force as of December 2007 until July 2008.

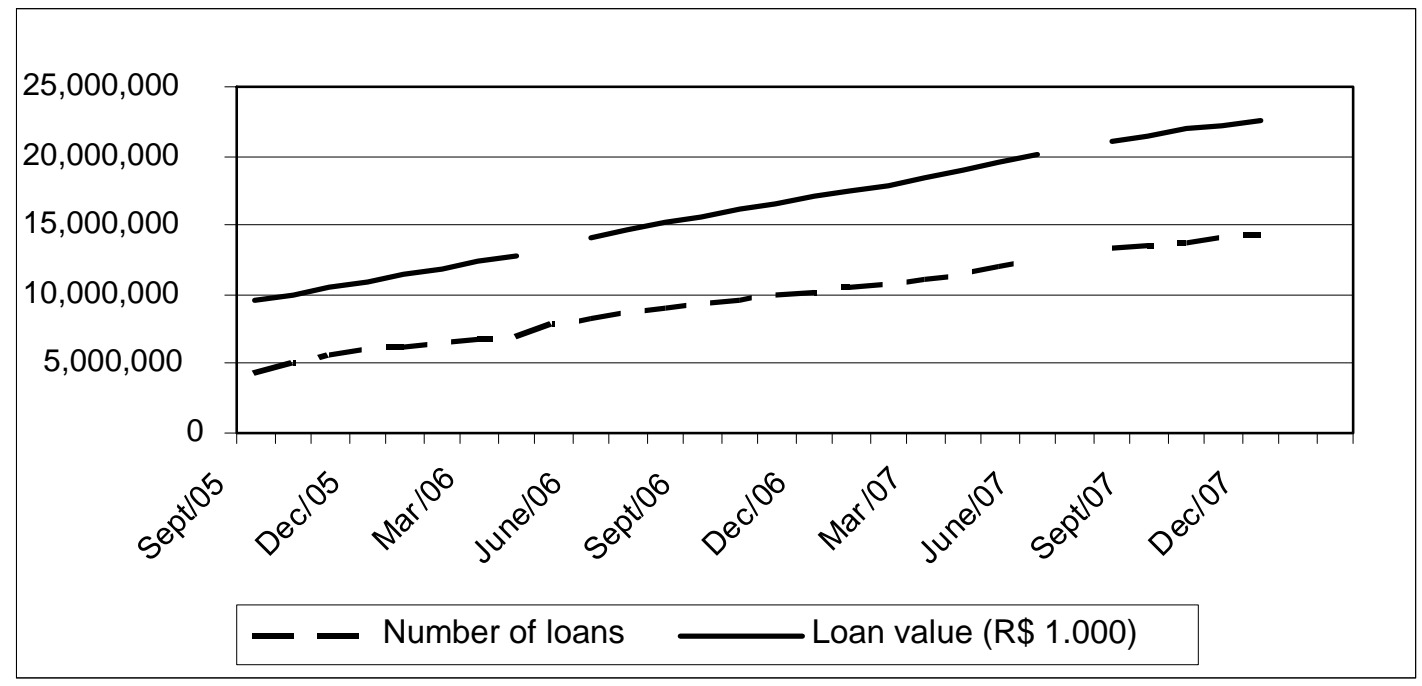

GRAPH 4: PAYROLL LOANS - INSS

Source: DATAPREV

Note. Dataprev (the INSS database) does not have data for May 2006 and July 2007.

It can be seen that the policy of the INSS and Social Security Ministry was to reduce the upper limit on the allowable interest rate and the amount of each installment, relaxed somewhat by allowing a longer repayment period, to increase the available income of borrowers during the amortization period.

Table 2: INSS payroll loans rules

\begin{tabular}{l|l|l|l}
\hline \multicolumn{2}{l|}{ Date of effectiveness } \\
\hline Maximum values & Until Dec. 2007 & As of Jan. 2008 & As of March 2008 \\
\hline Interest rate & $2.64 \%$ per month & $2.64 \%$ per month & $2.50 \%$ per month \\
\hline $\begin{array}{l}\text { Number of monthly } \\
\text { installments }\end{array}$ & 36 & 60 & 60 \\
\hline Installment amount & $\begin{array}{l}30 \% \text { of the net monthly } \\
\text { benefit }\end{array}$ & $\begin{array}{l}20 \% \text { of the net monthly } \\
\text { benefit }\end{array}$ & $\begin{array}{l}20 \% \text { of the net monthly } \\
\text { benefit }\end{array}$ \\
\hline $\begin{array}{l}\text { Loan origination fee } \\
\text { Prohibited } \\
\text { May 2006 }\end{array}$ & Prohibited since May 2006 & Prohibited since May 2006 \\
\hline
\end{tabular}

Source: INSS/DC Normative Instruction 121/05; INSS/PRES Normative Instructions 24/07 and 25/08; and MPS/CNPS Resolution 1295/08 


\section{CREDIT'S COST DETEMINANTS}

The cost of bank credit is basically determined by banks' funding cost plus the bank spread. The bank spread is the difference between the interest rate paid to depositors or other funding sources and the rate charged to borrowers (COSTA \& NAKANE, 2004).

According to Costa \& Nakane (2004), the domestic funding cost in Brazil is based on the Selic rate (benchmark rate) and the bank spread is composed of two elements, called cost factors and margin factors.

Cost factors consist of the operational and administrative costs associated with banking activity and the regulatory costs of financial intermediation. These cost factors are:

operational and administrative costs. Troster [200-] states that banking activity, because of its sophistication, requires highly trained workers, advanced technology and complex infrastructure, making these costs high.

- $\quad$ reserve requirement cost. The reserve requirements on cash deposits, term and passbook savings account deposits affect the spread by reducing the total amount of funds available for lending.

- $\quad$ cross subsidies. According to Nakane (2003), the existence of directed lending at subsidized rates (e.g., crop loans and mortgages) means that part of the spread charged on non-directed credit reflects an element of compensation by these transactions.

- $\quad$ cost of the Credit Guarantee Fund $(F G C)$. This fund is formed by contributions from financial institutions and is intended to protect investors and accountholders against intervention, extrajudicial liquidation, bankruptcy or insolvency of banks. It is financed by a levy of $0.0125 \%$ on guaranteed deposits (maximum of $\mathrm{R} \$$ 60 thousand), limited at $2 \%$ of the total of these accounts. This affects the bank intermediation cost by reducing the volume of resources available for loans.

- tax costs. Various taxes fall directly and indirectly on financial intermediation. The main ones are PIS, COFINS, IOF, IR and CSLL ${ }^{\mathrm{v}}$. 
- costs of loan default. The default rate must be deducted from the return on loans to define the rate effectively received by banks. According to the Brazilian Central Bank's calculation method, in 2006 default was the main component of the bank spread in Brazil. Oreiro \& Paula (2005) add that the growth rate of industrial output affected negatively both high default rates and by reduced demand for credit.

- legal risk. Troster [200-] observes that the inefficient judicial system (with costly and slow proceedings) aggravates default costs. Costa \& Mello (2006), in studying the effects of a decision by the Superior Tribunal of Justice (the highest court for non-constitutional matters) in July 2004 that held payroll loans to be illegal (a decision later overturned), found evidence that this decision had a negative impact by increasing the interest rate on loans and reducing the volume of credit offered by banks.

The second element, margin factor, refers to the remuneration of the bank's capital, that is, the gains from intermediation activity, net of the inherent costs of this activity. The determinants of the margin factor are:

- competition. According to Oreiro \& Paula (2005), despite the recent increase in banking concentration (and resulting reduction of competition) in Brazil, the evidence of the effect of this higher concentration on the bank spread does not appear to be conclusive. A similar view was expressed by Nakane (2003), who showed that in the period from 1994 to June 2003 the number of banks in Brazil fell from 246 to 164. However, he cited three works that had rejected the hypothesis that Brazilian banks behave as if there was perfect competition, but also rejected the hypothesis that they behave as a cartel or in collusion.

- opportunity cost. Banks can invest the funds on deposit in public bonds, which interest rate yield an high real return in the last years.,.

- transfer cost. According to Nakane (2003), types of credit tied to maintenance of bank accounts, such as overdraft checks for individuals and guarantee accounts for businesses, are typical of situations where customers are tied to a particular bank, due to the difficulty of transferring their banking history and reputation data to competing institutions.

As a result of these high transfer costs, the interest rates charged on these types of credit are markedly higher than on loan types where this does not occur. 
The Brazilian Central Bank (BCB, 2006) published the composition of the bank spread shown in Table 3. The figures in this table should be analyzed with care, since they show the composition of the spread, not its dynamic.

For example, the greater participation in 2006 than in 2005 of the "default" item in the total spread can be explained either by an increase in default or a relative reduction of one of more of the other components.

It can be seen that the spread is mainly explained by administrative costs and loan default, and that in more recent years the latter grew in importance.

Table 3: Decomposition of the bank spread - Proportion (\%)

\begin{tabular}{|c|c|c|c|c|c|c|}
\hline Item & 2001 & 2002 & 2003 & 2004 & 2005 & 2006 \\
\hline 1 - Total spread & 100.0 & 100.0 & 100.0 & 100.0 & 100.0 & 100.0 \\
\hline 2 - Administrative costs & 16.8 & 14.7 & 19.5 & 19.8 & 17.2 & 16.9 \\
\hline 3 - Loan default & 30.7 & 31.2 & 31.7 & 34.0 & 35.9 & 43.4 \\
\hline 4 - Reserve requirement & 9.7 & 12.2 & 6.5 & 7.0 & 5.0 & 4.7 \\
\hline Cash deposits & 9.4 & 10.0 & 7.1 & 6.8 & 5.1 & 4.9 \\
\hline Term deposits & 0.3 & 3.2 & -0.6 & 0.1 & -0.1 & -0.3 \\
\hline 5 - Indirect taxes and FGC & 7.0 & 7.3 & 7.2 & 8.4 & 8.1 & 8.6 \\
\hline Indirect taxes & 6.8 & 7.0 & 7.0 & 8.1 & 7.8 & 8.3 \\
\hline FGC cost & 0.3 & 0.3 & 0.3 & 0.3 & 0.3 & 0.3 \\
\hline 6 - Gross residual (1-2-3-4-5) & 35.7 & 34.7 & 35.1 & 30.8 & 33.8 & 26.4 \\
\hline 7 - Direct taxes & 12.1 & 11.0 & 10.6 & 9.9 & 9.5 & 7.3 \\
\hline $8-$ Net residual (6-7) & 23.6 & 23.7 & 24.4 & 21.0 & 24.3 & 19.0 \\
\hline
\end{tabular}

Source: Brazilian Central Bank (2006)

An important point here is that default is the only observable cost factor that varies according to borrowers' characteristics.

\section{RESEARCH PROBLEM}

The supply of personal credit in Brazil in recent years has grown substantially, and automatic debit loans have played an important role in this development. This was particularly true in 2005 and 2006. 
Therefore, it is interesting to perform a quantitative analysis of the characteristics and conditions for granting these loans to social security beneficiaries.

The literature has shown, for example, that credit and economic growth are positively correlated (for example, see De Gregorio \& Guidotti, 1995 ${ }^{\mathrm{vi}}$ ).

Nevertheless, in Brazil little research has been done on payroll loans in general. The few works published on this type of credit generally focus on the interest rates charged, using econometric models, and have not been very conclusive ${ }^{\mathrm{vii}}$.

Given the relevance of the theme (the recent growth of the number and volume by value of automatic deduction loans to social security beneficiaries, their reflections on the policies of the Social Security Ministry and the recognized importance of the credit channel to wage and economic growth) and the shortage of works on the subject, we believe the present study is timely.

Our aim is to investigate whether the rate of return on INSS deduction loans is the same as that obtained on payroll deduction loans. By rate of return we mean the real return obtained by financial institutions after considering the costs and possible additional fees charged on loan transactions.

The novelty of the empirical part of this study is the incorporation of the cost represented by biometric risk, that is, the risk that the borrower will die before paying back the loan.

This risk is particularly relevant in the case of social security beneficiaries, since they are obviously on average older than other groups and have a higher probability of dying. For this it is necessary to incorporate an actuarial mathematical exercise into the usual financial mathematical calculation, represented by the granting and repayment of loans. This actuarial aspect is described in the next section.

\section{METHODOLOGY}

To obtain the rate of return on a banking transaction, in the case here an INSS deduction loan, it is necessary to ascertain the revenues from the transaction and compare them ex post with the associated costs and expenses.

However, the objective of this study is to compare the rate of return on INSS deduction loans with that on payroll deduction loans. In other words, the methodological 
path is to consider the social security beneficiaries (retires and receivers of survivor benefits) as the treatment group, as defined by Wooldridge (2002, Ch. 18).

The next step is to find a control group. Ideally this group should contain a set of individuals with observable characteristics as near as possible to those of the treatment group, with the exception of one, which will serve as an element to identify and differentiate the two groups. The more homogeneous these two groups are, the more adequate the methodology.

For this reason, attention should first be focused on the characteristics of the credit market, as presented in the preceding sections.

Then attention should be turned to finding the factors that differentiate the costs of payroll loans to social security beneficiaries and those of payroll loans to salaried employees.

Analysis of the factors composing the bank spread, presented in the previous section and summarized in Table 3, shows that default is the only observable cost factor that varies according to the borrowers' characteristics.

All other components of the spread are related to the characteristics of other agents (federal government and banking system) and the legal-institutional framework, all of which are independent of the borrowers' characteristics.

Besides this, we assume these other components homogeneously affect those receiving payroll loans (whether social security beneficiaries or salaried employees), and thus do not justify differences in the rate of return obtained by banks on these transactions.

Therefore, the cost factor we focus on here to compare the rates of return on the two types of payroll loans is default. In the case of payroll loans to social security beneficiaries (treatment group), the default cost is basically associated with the risk the borrower will die before paying off the loan (biometric risk), since the automatic deduction from benefits rules out default.

As a control group (for comparison and evaluation of the result) we chose payroll borrowers made up of employees of the São Paulo Municipal Government (PMSP). 
The justification for this choice is that this group has very similar observable characteristics as the treatment group.

The control group's default risk is similar, given the job stability enjoyed by civil servants, except for the biometric factor.

As can be seen in Table 4, which presents the restrictions of municipal legislation on payroll deduction loans to PMSP employees, these are no stricter than on loans to social security beneficiaries (Table 2).

In other words, the characteristic that differentiates the rates of return on loans to the treatment group and the control group is biometric risk.

This difference is due to the fact that the average age of active civil servants is substantially lower than that of social security beneficiaries, which should be reflected in the cost of default.

Table 4: Rules on payroll loans to São Paulo Municipal Government employees (in effect as of April 2008)

\begin{tabular}{|c|c|}
\hline Item & Maximum value \\
\hline Interest rate & $2.50 \%$ per month \\
\hline Number of monthly installments & No limit \\
\hline Installment amount & $40 \%$ of the net monthly pay \\
\hline Loan origination fee $\mathrm{e}^{\text {viii }}$ & Prohibited since April 2008 \\
\hline
\end{tabular}

Source: Decree 48425/08; SMG Edict 54/08; and MPS/CNPS Resolution 1295/08.

Therefore, we examine the following hypotheses, null $\left(H_{0}\right)$ and alternative $\left(H_{1}\right)$ :

$\mathrm{H}_{0}$ : Given the biometric risk (default by death), the rate of return obtained by banks on INSS deduction loans is equal to the rate of return on payroll loans to PMSP employees.

$\mathrm{H}_{1}$ : Given the biometric risk (default by death), the rate of return obtained by banks on INSS deduction loans is different than the rate of return on payroll loans to PMSP employees.

To test these hypotheses we obtained data on the nominal interest rates charged on payroll loans to the two groups.

The data were gathered in the first half of June 2008 from 23 banks and are presented in Table 5 ix $^{\text {ix }}$ 
At the time the study was conducted, 56 banks had agreements with the INSS for deducting loan repayments, allowing them to extend payroll loans to social security beneficiaries.

Of these 56 banks, we chose 23 to survey, from the list of the 50 largest banks in March 2008 provided by the Brazilian Central Bank (classified by total assets).

Of these banks, two replied that they do not make this type of loan to INSS beneficiaries, five stated they do not lend to PMSP employees and four replied they do not lend either to INSS beneficiaries or PMSP employees (these four are not shown in Table 5 above).

As can be seen, the nominal interest rate charged to INSS beneficiaries is on average higher than that charged to PMSP employees.

However, it is necessary to consider that the PMSP deducts $2 \%$ of the installment transferred to the bank as a processing fee and to evaluate to what point this cost reduces the banks' rate of return on these loans, and at the same time to what point the greater biometric risk reduces the rate of return on loans to INSS beneficiaries.

Table 5: Nominal interest rates charged by banks (\% per month)

\begin{tabular}{|c|c|c|c|c|}
\hline \multirow[t]{2}{*}{ Financial Institution } & \multicolumn{2}{|c|}{ INSS Beneficiaries } & \multicolumn{2}{|c|}{ PMSP Employees } \\
\hline & 36 months & 60 months & 36 months & 60 months \\
\hline Bank1. & 2.30 & 2.35 & 2.34 & 2.34 \\
\hline Bank2. & 2.30 & 2.45 & 1.90 & 2.26 \\
\hline Bank3. & 2.45 & 2.50 & \multicolumn{2}{|c|}{ Does not offer } \\
\hline Bank4. & \multicolumn{2}{|c|}{ Does not offer } & 2.50 & 2.50 \\
\hline Bank5. & 2.35 & 2.45 & 1.90 & 1.90 \\
\hline Bank7. & 2.50 & 2.50 & \multicolumn{2}{|c|}{ Does not offer } \\
\hline Bank8. & 2.30 & 2.30 & & \\
\hline Bank10. & 2.50 & 2.50 & 2.20 & 2.20 \\
\hline Bank11. & 2.49 & 2.49 & 2.30 & 2.10 \\
\hline Bank12. & 2.64 & \multicolumn{3}{|c|}{ Does not offer } \\
\hline Bank13. & \multicolumn{2}{|c|}{ Does not offer } & 2.20 & 2.14 \\
\hline Bank14. & 2.47 & 2.48 & 2.30 & 2.22 \\
\hline Bank15. & 2.00 & 2.00 & 2.50 & 2.50 \\
\hline Bank16. & 2.49 & 2.49 & 2.45 & 2.45 \\
\hline Bank17. & 2.45 & 2.48 & 1.90 & 1.90 \\
\hline Bank18. & 2.49 & 2.49 & 2.27 & 2.24 \\
\hline Bank20. & 2.50 & 2.50 & 2.00 & 1.90 \\
\hline
\end{tabular}




\begin{tabular}{l|l|l|l|l}
\hline Bank21. & 2.59 & 2.59 & \multicolumn{2}{|l}{ Does not offer } \\
\hline Bank22. & 2.45 & 2.38 & 2.45 & 2.20 \\
\hline Average & $\mathbf{2 . 4 3}$ & $\mathbf{2 . 4 3}$ & $\mathbf{2 . 2 3}$ & $\mathbf{2 . 2 0}$ \\
\hline Percentage of respondents & $\mathbf{7 3 . 9 1 \%}$ & $\mathbf{6 9 . 5 7 \%}$ & $\mathbf{6 0 . 8 7 \%}$ & $\mathbf{6 0 . 8 7 \%}$ \\
\hline So:
\end{tabular}

Source: Survey by the authors.

\subsection{The Model}

As already discussed, only examining the possible cost of default given by the biometric risk of both groups leads to the inference that there is a difference in the rate of return between the treatment and control groups, since all other cost factors can be considered equal for both groups.

To test hypotheses $H_{0}$ and $H_{l}$, we calculated what we call the Rate of Return after Default Costs (RRADC), obtained by calculating the internal rate of return (IRR), plus the biometric risk (and the possible risk factor this represents for each group) and the transfer fee (TF) charged by the PMSP on the loan payments transferred to the lending banks.

Equation 1 shows the calculation of the IRR without including the biometric risk and transfer fee. In it, $A M_{t}$ is the amount the monthly installment to be paid in month $t$, $L V$ is the loan value, $n$ is the number of monthly installments and IRR is the internal rate of return, which equals the present value of the $A M_{t}$ installments at the contracted value $L V$.

$$
L V=\sum_{t=1}^{n} \frac{A M_{t}}{(1+I R R)^{t}}
$$

The loan is fully amortized ${ }^{\mathrm{x}}$, meaning all the payments are equal (no balloon payment). In this case the amount of the installments $A M$ is calculated according to equation $2^{\mathrm{xi}}$, where $j$ is the nominal interest rate charged by the bank (shown in Table 5), $T F$ is the transfer fee and the expression $(1-T F)$ makes $A M$ represent the amount actually received by the bank.

$$
A M=(1-T F) \times(L V) \times\left(\frac{j(1+j)^{n}}{(1+j)^{n}-1}\right)
$$


To obtain the RRADC, it is necessary to incorporate the biometric risk component into equation 1 . To do this, the amount of each installment $A M$ is multiplied by the probability that a borrower with age $\mathrm{x}$ years will survive $x+t$ months.

In other words, this gives the expected value of each installment, based on the probability that the borrower will survive over the life of the loan.

As presented by Vilanova (1969, Ch. I and II) and Parmenter (1999, Ch. 7), this probability, which represents the biometric risk factor, designated by the terms ${ }_{t} P_{x}$ according to standard actuarial notation, is given by equation 3 , in which $l_{x}$ is the number or living persons (survivors) of a determined cohort with age $x$ and $l_{x+t}$ indicates the number of living persons (survivors) of this same cohort with age $x+t$.

$$
, p_{x}=\frac{l_{x+1}}{l_{x}}
$$

The values of $l_{x}$ employed to calculate the biometric risk factor ${ }_{t} P_{x}$ were obtained from the mortality table calculated and disclosed by the Brazilian Institute of Geography and Statistics (IBGE, 2006), which is used by the INSS to calculate the "social security

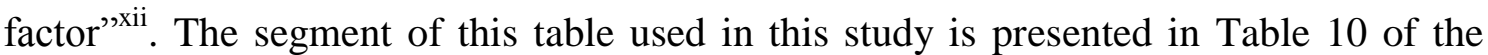
Appendix.

Given the relatively short loan maturities and the fact the payments are monthly, it is necessary to perform an additional calculation based on this mortality table, since it only presents annual values of $l_{x}$ and here we need monthly values.

We estimated the monthly values of $l_{x}$ by an ordinary least squares (OLL) regression, employing the annual data for $l_{x}$ calculated by the IBGE (2006) for people 30 to 80 years old. The model estimated is presented in equation 4 .

The age, utilized to estimate the number of survivors $\left(l_{x}\right)$, was included in the model up to the third degree to enable capturing the curve's non-linearity and to obtain good fit with the real data.

$$
I_{x}=\beta_{0}+\beta_{1} \cdot a g e+\beta_{2} \cdot a g e^{2}+\beta_{3} \cdot a g e^{3}
$$


The results of the econometric procedure are presented in Table $6^{\text {xiii }}$. Based on the estimated coefficients it is possible to predict the values of $l_{x}$ corresponding to the monthly ages.

Graph 6 in the Appendix depicts the data represented by applying the equation estimated in Table 6 together with the data in the IBGE's mortality table.

The results of the estimation reported in Table 6 allow calculation of the monthly values for the biometric risk factor ${ }_{t} P_{x}$. of equation 3 .

Table 11 of the Appendix presents the calculation of ${ }_{t} P_{x}$ from 30 to 35 years old based on the equation estimated in Table 6 .

The calculation is analogous for the other values of ${ }_{t} P_{x}$ utilized in this work. These values are multiplied by equation 2 and incorporated into equation 1, producing equation 5, which enables calculating the RRADC.

Term $A$ of equation 5 represents the financial factor of the calculation, discounting the installment payment to present value.

Term $B$ represents the calculation of the installment amount for a fully amortized loan after deducting the transfer fee $(T F)$ charged by the PMSP, based on the average contracted loan value $(L V)$.

Finally, term $C$ represents the biometric risk associated with the loan, incorporated into the calculation. The older the borrower, the higher the biometric risk will be.

Table 6: OLL regression. Dependent variable: $l_{x}$

\begin{tabular}{l|c}
\hline \multicolumn{1}{c|}{ Variable } & Estimated coefficient \\
\hline Age & $-1,695.112$ \\
\hline $\mathrm{Age}^{2}$ & $(-46.351)^{* *}$ \\
\hline & 42.067 \\
\hline $\mathrm{Age}^{3}$ & $(61.17729)^{* *}$ \\
\hline & -0.411 \\
\hline Intercept & $(-98.91211)^{* *}$ \\
\hline & $118,628.032$ \\
\hline Number of observations & $(190.71404)^{* *}$ \\
\hline$R^{2}$ & 51 \\
\hline
\end{tabular}




$$
L V=\sum_{i=1}^{*}(\underbrace{\left.\frac{1}{(1+I R R)^{\prime}} \times\left[(1-T F) \times(L V) \times\left(\frac{j(1+j)^{n}}{(1+j)^{n}-1}\right)\right] \times, P_{N}\right)}_{\mathrm{A}} \underbrace{\underbrace{}_{\mathrm{C}}}_{\mathrm{B}}
$$

We chose the parameters used in equation 5 to calculate the RRADC based on the average of INSS deduction loans in November 2007 (latest data made available by Dataprev): term of 36 or 60 months $^{\text {xiv }}(n=36$ or 60$)$ and average loan value $(L V)$ equal to $\mathrm{R} \$ 1,585.00$. The interest rates $(j)$ are different for each bank, as shown in Table 5.

Since Dataprev does not disclose the average age of retirees and receivers of survivor benefits who take out loans secured against their future benefits, we performed simulations of these loans at three ages: 50,60 and 70 years. For payroll deduction loans taken out by civil servants, we used ages of 30 and 40 years.

\section{RESULTS}

Using the parameters adopted along with the cost discount values and the interest rates charged by each bank, we calculated the RRADC values with equation 5 .

The results for each bank are presented by borrower's age (50, 60 or 70 years) and loan term (36 or 60 months) in Table 7 (social security beneficiaries) and Table 8 (São Paulo municipal employees). A summary of the average results is presented in Graph 5.

As expected, the RRADC declines as the age of the social security beneficiary increases, directly reflecting the higher probability of death and thus of loan default.

Table 7: RRADC - INSS deduction loans (\% per month)

\begin{tabular}{l|c|c|c|c|c|c}
\hline \multirow{2}{*}{ Financial Institution } & \multicolumn{5}{c}{ Loan term } \\
\cline { 2 - 7 } & \multicolumn{3}{|c}{$\mathbf{3 6}$ months } & \multicolumn{3}{c}{$\mathbf{6 0}$ meses } \\
\cline { 2 - 7 } & $\mathbf{5 0}$ years & $\mathbf{6 0}$ anos & $\mathbf{7 0}$ years & $\mathbf{5 0}$ years & $\mathbf{6 0}$ years & $\mathbf{7 0}$ years \\
\hline Bank1. & 2.24 & 2.18 & 2.04 & 2.29 & 2.22 & 2.08 \\
\hline Bank2. & 2.24 & 2.18 & 2.04 & 2.39 & 2.32 & 2.18 \\
\hline Bank3. & 2.39 & 2.33 & 2.19 & 2.44 & 2.37 & 2.23 \\
\hline
\end{tabular}




\begin{tabular}{|c|c|c|c|c|c|c|}
\hline Bank5. & 2.29 & 2.23 & 2.09 & 2.39 & 2.32 & 2.18 \\
\hline Bank7. & 2.44 & 2.38 & 2.24 & 2.44 & 2.37 & 2.23 \\
\hline Bank8. & 2.24 & 2.18 & 2.04 & 2.24 & 2.17 & 2.03 \\
\hline Bank10. & 2.44 & 2.38 & 2.24 & 2.44 & 2.37 & 2.23 \\
\hline Bank11. & 2.43 & 2.37 & 2.23 & 2.43 & 2.36 & 2.22 \\
\hline Bank12. & 2.58 & 2.52 & 2.38 & \multicolumn{3}{|c|}{ Does not offer } \\
\hline Bank14. & 2.41 & 2.35 & 2.21 & 2.42 & 2.35 & 2.21 \\
\hline Bank15. & 1.94 & 1.88 & 1.74 & 1.94 & 1.87 & 1.73 \\
\hline Bank16. & 2.43 & 2.37 & 2.23 & 2.43 & 2.36 & 2.22 \\
\hline Bank17. & 2.39 & 2.33 & 2.19 & 2.42 & 2.35 & 2.21 \\
\hline Bank18. & 2.43 & 2.37 & 2.23 & 2.43 & 2.36 & 2.22 \\
\hline Bank20. & 2.44 & 2.38 & 2.24 & 2.44 & 2.37 & 2.23 \\
\hline Bank21. & 2.53 & 2.47 & 2.33 & 2.53 & 2.46 & 2.32 \\
\hline Bank22. & 2.39 & 2.33 & 2.19 & 2.32 & 2.25 & 2.11 \\
\hline Average & 2.37 & 2.30 & 2.17 & 2.37 & 2.31 & 2.16 \\
\hline
\end{tabular}

Source: Authors' calculations

Note that the average RRADC does not change much between loan maturities of 36 months and 60 months, although there are a few more substantial differences for particular banks, such as Bank 22.

The same general remarks regarding the variation of the RRADC with age and loan maturity for social security beneficiaries in Table 7 apply to PMSP employees in Table 8.

A further observation is that in the latter case, the average RRADC declines less with the age variation. This is expected, since the increased probability of death is lower between the ages of 30 and 40 years than between 50 and 70 years.

Graph 5 shows that the RRADC obtained by banks on INSS deduction loans is much higher than that on loans to PMSP employees, which corroborates the alternative hypothesis $\left(H_{1}\right)$. 
Table 8: RRADC - Payroll deduction loans (PMSP employees) (\% per month)

\begin{tabular}{l|c|c|c|c}
\hline \multirow{2}{*}{ Financial institution } & \multicolumn{3}{c}{ Loan term } \\
\cline { 2 - 5 } & \multicolumn{2}{|c}{ 36 months } & \multicolumn{2}{c}{ 60 months } \\
\cline { 2 - 5 } & $\mathbf{3 0}$ years & $\mathbf{4 0}$ years & $\mathbf{3 0}$ years & $\mathbf{4 0}$ years \\
\hline Bank1. & 2.19 & 2.18 & 2.23 & 2.22 \\
\hline Bank2. & 1.75 & 1.75 & 2.15 & 2.14 \\
\hline Bank4. & 2.35 & 2.34 & 2.39 & 2.38 \\
\hline Bank5. & 1.75 & 1.75 & 1.79 & 1.79 \\
\hline Bank10. & 2.05 & 2.04 & 2.09 & 2.08 \\
\hline Bank11. & 2.15 & 2.14 & 1.99 & 1.99 \\
\hline Bank13. & 2.05 & 2.04 & 2.03 & 2.02 \\
\hline Bank14. & 2.15 & 2.14 & 2.11 & 2.10 \\
\hline Bank15. & 2.35 & 2.34 & 2.39 & 2.38 \\
\hline Bank16. & 2.30 & 2.29 & 2.34 & 2.33 \\
\hline Bank17. & 1.75 & 1.75 & 1.79 & 1.79 \\
\hline Bank18. & 2.12 & 2.11 & 2.13 & 2.12 \\
\hline Bank20. & 1.85 & 1.85 & 1.79 & 1.79 \\
\hline Bank22. & 2.30 & 2.29 & 2.09 & 2.08 \\
\hline Average & $\mathbf{2 . 0 8}$ & $\mathbf{2 . 0 7}$ & $\mathbf{2 . 1 0}$ & $\mathbf{2 . 0 9}$ \\
\hline Source: Authyyyyyy & & & & \\
\hline
\end{tabular}

Source: Authors' calculations

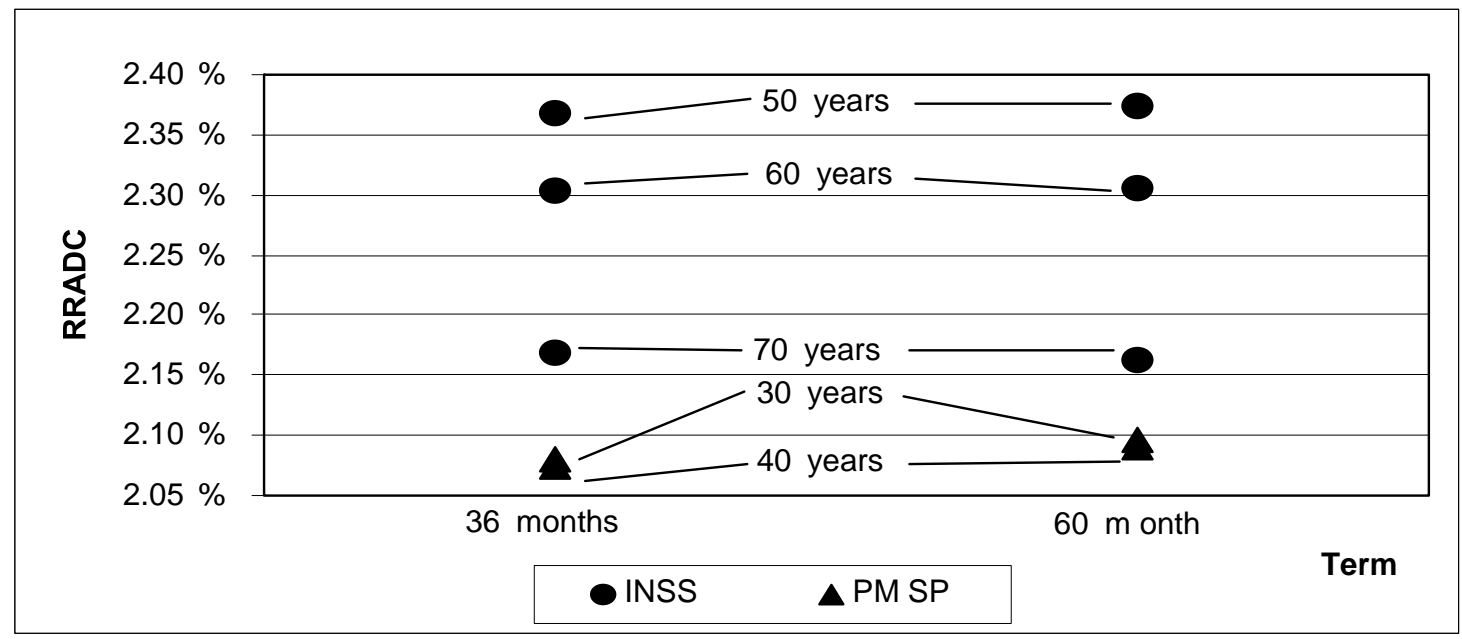

GRAPH 5: AVERAGE OF THE RRADCS OF THE FINANCIAL INSTITUTIONS (BY BORROWER'S AGE AND LOAN TERM)

Source: Authors' calculations (Tables 7 and 8)

Some considerations can be made based on the results of Tables 7 and 8. As explained in the methodology section, the RRADC index does not represent the bank's actual rate of return. 
Each institution also has to cover the other cost factors analyzed previously, with the exception of the default costs (administrative overhead, reserve requirement, taxes, etc.).

Since these costs, though differing among banks, are virtually the same for the treatment and control groups, the result of the differences in the effective rates charged by the banks is not affected. Indeed, our aim is not to measure these rates.

On average the loan conditions to social security beneficiaries imply higher RRADC values than for payroll loans to São Paulo municipal employees.

In other words, within the sample of financial institutions analyzed, it can be affirmed that the return obtained on INSS deduction loans is higher than that on payroll deduction loans to PMSP employees.

\subsection{Sensitivity analysis}

To check the sensitivity of the results presented in Tables 7 and 8 to variations in the parameters, we performed an additional simulation, altering the loan value to $\mathrm{R} \$$ $5,000.00$.

The results are presented for the same terms (36 and 60 months) and borrowers' age (30 or 40 years for PMSP employees and 50, 60 or 70 years for INSS beneficiaries). The average results of the banks are presented in Table 9.

Table 9: Sensitivity analysis of the RRADC. Loan value $=\mathbf{R} \$ \mathbf{5 , 0 0 0 . 0 0}(\%$ per month)

\begin{tabular}{|c|c|c|c|c|c|}
\hline & PMSP & $\begin{array}{c}\text { payroll } \\
\text { deduc } \\
\text { tion }\end{array}$ & \multicolumn{3}{|c|}{ INSS deduction loans } \\
\hline & 30 years & 40 years & 50 years & 60 years & 70 years \\
\hline & \multicolumn{5}{|c|}{ Term: 36 months } \\
\hline \multirow[t]{2}{*}{ Average of the banks } & 2.08 & 2.07 & 2.37 & 2.30 & 2.17 \\
\hline & \multicolumn{5}{|c|}{ Term: 60 months } \\
\hline Average of the banks & 2.10 & 2.09 & 2.37 & 2.31 & 2.16 \\
\hline
\end{tabular}

Source: Authors' calculations

Comparison of Tables 7 and 8 against Table 9 shows that the average RRADC of the loans to both the treatment and control groups remains stable to the second decimal place when the loan value varies. 
This means that in the case of the sample analyzed, a change in the controllable variables appears not to affect the fact the rate of return obtained by banks on INSS deduction loans is higher than that on payroll deduction loans to PMSP employees.

Therefore, we it is reasonable to affirm that the differences observed in Tables 7 and 8 hold for Table 9, with different parameters.

This is probably a reflection of the fact the loan value is not a relevant explanatory variable to differentiate the two groups, which strengthens the importance of incorporating the biometric risk factor.

\section{FINAL COMMENTS}

In this article we sought to incorporate and quantify the role of biometric risk in loans to social security beneficiaries secured by deduction from future benefits. To do this, we employed a control group, composed of São Paulo Municipal Government employees.

The results obtained do not indicate rejection of the alternative hypothesis $\left(H_{1}\right)$, meaning that for the sample analyzed the rate of return obtained by banks on INSS deduction loans is different (and higher) than the rate obtained on automatic debit loans to other individuals.

This means that the financial institutions in the sample analyzed obtain more profit from payroll loans to INSS beneficiaries than from payroll loans to São Paulo municipal employees.

These results are relevant for the formulation of public policies by the Social Security Ministry, particularly with respect to the maximum interest rates that banks can charge on automatic debit loans to social security beneficiaries.

The results are also important to clarify to interested groups and to society at large the different treatment with respect to profit margins given by banks to the two groups of customers.

Nevertheless, care should be taken in any attempt to generalize the conclusions reached, since they are highly dependent on the sample and the control group utilized in this study.

Given the importance that INSS deduction loans have gained within the personal loan category in recent years, payroll loans deserves further empirical study, which could corroborate the results presented here. 
The increasing importance over the past five years of automatic debit loans in general, both in volume of resources lent and number of loans, is a novel development for the Brazilian economy.

Because it is a recent phenomenon, there are few contributions on the theme. Rodrigues et al. (2006), using a matching model, showed that payroll loans borrowers pay an average interest rate 12.73 percentage points lower than other individuals with the same characteristics.

This result is corroborated by Coelho (2007, Ch. 3), through a differenceindifference model, the results of which indicated that automatic debit loans permit an increase of $42 \%$ in the volume of credit and a reduction of $10.3 \%$ in the interest rates. But neither of these studies included biometric risk, as in this article.

Finally, we can mention two possible extensions of this study. The first, related to the geographic dimension, refers to investigating the possibility that the results could differ for different regions of the country.

Not only could the interest rates differ according to the regions, but people in poorer regions also tend to have shorter life expectancies, which would increase the risk involved on loans secured by social security benefit deductions.

Another factor is that social security benefits are more important in poorer regions, which could make this type of credit more important in those regions. A second possible extension would be to estimate the existing demand for this type of credit. This could be done by aggregating the average loan amount for each population of social security beneficiaries.

\section{REFERENCES}

BANCO CENTRAL DO BRASIL (BCB). 50 Maiores Banco e o Consolidado do Sistema Financeiro Nacional. March 2008. Available at <http://www.bcb.gov.br/fis/TOP50/port/Top502008030P.asp>. Accessed on: June 15, 2008.

\section{BANCO CENTRAL DO BRASIL (BCB). Boletim Mensal do Banco Central do}

Brasil. Dec. 2007. Available at < http://www.bcb.gov.br/ftp/histbole/BT200712P.ZIP>. Accessed on: Jan. 30, 2008. 
Economia Bancária e Crédito: Avaliação de 3 anos do projeto juros e spread bancário. Dec. 2002. Available at <http://www.bcb.gov.br/?SPREAD3ANO>. Accessed on: Jan. 30, 2008.

Economia Bancária e Crédito: Avaliação de 4 anos do projeto juros e spread bancário. Dez/2003. Available at <http://www.bcb.gov.br/?SPREAD4ANO>. Accessed on: Jan. 30, 2008.

Economia Bancária e Crédito: Avaliação de 5 anos do projeto juros e spread bancário. Dec. 2004. Available at <http://www.bcb.gov.br/?SPREAD5ANO>. Accessed on: Jan. 30, 2008.

Relatório de Economia Bancária e Crédito. 2005. Available at <http://www.bcb.gov.br/?RELECONCRED>. Accessed on: Jan. 30, 2008.

Relatório de Economia Bancária e Crédito. 2006. Available at <http://www.bcb.gov.br/?RELECON06>. Accessed on: Jan. 30, 2008.

Séries Temporais. Available at <http://www.bcb.gov.br/?SERIETEMP>. Accessed on: Jan. 30, 2008.

BARROS, João Paulo de Oliveira; FAGUNDES, Maria Emília Marques;

CAVALCANTE, Luiz Ricardo. Spread bancário em operações de crédito consignado no Brasil. Revista Desenbahia, n. 7, Sept., pp. 65-85, 2007.

BRASIL. Instrução Normativa INSS/DC $n^{\circ} 121$ de 01 de julho de 2005. Diário Oficial da União, Poder Executivo, DF, July 7, 2005.

Instrução Normativa INSS/PRES no 24 de 19 de dezembro de 2007. Diário Oficial da União, Poder Executivo, DF, Dec. 20, 2007.

Instrução Normativa INSS/PRES n 25 de 07 de janeiro de 2008. Diário Oficial da União, Poder Executivo, DF, Jan. 8, 2008.

Instrução Normativa INSS/PRES no 28 de 16 de maio de 2008. Diário Oficial da União, Poder Executivo, DF, May 19, 2008.

Lei $\mathrm{n}^{\circ} 8.112$ de 11 de dezembro de 1990. Diário Oficial da União, Poder Legislativo, Brasília, DF, Dec. 11, 1990.

Resolução BACEN nº 3.251 de 16 de dezembro de 2004. Poder Executivo.

Resolução CMN no 3.518 de 6 de dezembro de 2007. Diário Oficial da União, Poder Executivo, Brasília, DF, Dec. 10, 2007.

Resolução MPS/CNPS n 1.295 de 5 de março de 2008. Diário Oficial da União, Poder Executivo, Brasília, DF, March 7, 2008. 
BRUNI, Adriano Leal; FAMÁ, Rubens. Matemática Financeira: com HP 12C e Excel. São Paulo: Atlas, 2002.

COELHO, Christiano Arrigoni. Três ensaios sobre microeconomia bancária aplicada. Doctoral Thesis in Economics, Pontifícia Universidade Católica do Rio de Janeiro, 2007.

COSTA, Ana Carla Abrão; MELlO, João M. P. de. Judicial Risk and Credit Market Performance: Micro Evidence from Brazilian Payroll Loans. Brasília: Banco do Brasil, Working Paper Series, n. 102, April 2006. Available at <http://www.bcb.gov.br/pec/wps/ingl/wps102.pdf>. Accessed on: Jan. 30, 2008.

COSTA, Ana Carla Abrão; NAKANE, Márcio I. Revisitando a metodologia de decomposição do spread bancário no Brasil. São Paulo: Seminário Bacen-USP de Economia Monetária e Bancária, $2^{\circ}$ semestre de 2004. Available at <www.econ.fea.usp.br/bacen/Artigos/SpreadRevFinalset04.PDF>. Accessed on: Jan. 30, 2008.

DATAPREV. Crédito Consignado - INSS. Dec. 2007. Available at <http://www.previdencia.gov.br/agprev/docs/EmprestimoConsignado200711.xls> Accessed on: Jan. 30, 2008.

DE GREGORIO, Jose; GUIDOTTI, Pablo E. Financial development and economic growth. World Development, Vol. 23, No. 3, pp. 433-448, 1995.

INSTITUTO BRASILEIRO DE GEOGRAFIA E ESTATÍSTICA (IBGE). Tábuas Completas de Mortalidade - 2006. Available at <http://www.ibge.gov.br/home/estatistica/populacao/tabuadevida/2006/default.shtm>. Accessed on: Jan. 30, 2008.

NAKANE, Márcio I. Concorrência e Spread Bancário: uma Revisão da Evidência para o Brasil. In: BANCO CENTRAL DO BRASIL. Economia Bancária e Crédito:

Avaliação de 4 anos do projeto juros e spread bancário. Dec. 2003. pp. 58-67. Available at <http://www.bcb.gov.br/?SPREAD4ANO>. Accessed on: Jan. 30, 2008.

OREIRO, José Luís. PAULA, Luiz Fernando de. Fatores macroeconômicos do spread bancário. Valor Econômico, Jan. 12, 2005. Available at

<http://paginas.terra.com.br/educacao/luizfpaula/material_lf/artigos\%20e\%20entrevista s/fatores_macro_spread_bancario.pdf >. Accessed on: Jan. 30, 2008.

PARMENTER. Michael M. Theory of interest and life contingencies with applications: a problem-solving approach. Winsted: ACTEX, 1999.

RODRIGUES, Eduardo A. S.; CHU, Victorio; ALENCAR; Leonardo S.; TAKEDA, Tony. O efeito da consignação em folha nas taxas de juros dos empréstimos pessoais. Trabalhos para discussão. Banco Central do Brasil, n. 108, June 2006.

SÃO PAULO (Município). Decreto no 49.425 de 22 de abril de 2008. Diário Oficial do Município, Poder Legislativo, São Paulo, SP, April 23, 2008. 
SÃO PAULO (Município). Portaria SMG no 54 de 28 de março de 2008. Diário Oficial do Município, Poder Executivo, São Paulo, SP, March 28, 2008.

TAKEDA, Tony; BADER, Fani Lea C. Consignação em folha de Pagamento: Fatores da Impulsão do Crédito. In: BANCO CENTRAL DO BRASIL. Relatório de Economia Bancária e Crédito. 2005. pp. 69-87. Available at

<http://www.bcb.gov.br/?RELECONCRED>. Accessed on: Jan. 30, 2008.

TROSTER, Roberto Luís. Spread bancário no Brasil. FEBRABAN, Artigos e Análises [200-]. Available at

<http://www.febraban.org.br/Arquivo/Servicos/Imprensa/spreadbancario0307c.pdf $>$.

Accessed on: Jan. 30, 2008.

VILANOVA, Wilson. Matemática Atuarial. São Paulo: Edusp, 1969.

WOOLDRIDGE, Jeffrey M. Introductory Econometrics: A modern approach. 2nd ed. Mason: South-Western, 2003.

WOOLDRIDGE, Jeffrey M. Econometric Analysis of Cross Section and Panel Data. Cambridge: MIT Press, 2002.

\section{Appendix}

Table 10: Mortality table calculated by the IBGE for 2006 (both sexes)

\begin{tabular}{c|r|r|r|r|r}
\hline Age $(\mathrm{X})$ & \multicolumn{1}{|c|}{$1(\mathrm{X})$} & Age $(\mathrm{X})$ & $1(\mathrm{X})$ & Age $(\mathrm{X})$ & $1(\mathrm{X})$ \\
\hline 30 & 94,362 & 47 & 89,180 & 64 & 74,751 \\
\hline 31 & 94,160 & 48 & 88,678 & 65 & 73,372 \\
\hline 32 & 93,951 & 49 & 88,146 & 66 & 71,919 \\
\hline 33 & 93,735 & 50 & 87,584 & 67 & 70,389 \\
\hline 34 & 93,510 & 51 & 86,990 & 68 & 68,773 \\
\hline 35 & 93,277 & 52 & 86,361 & 69 & 67,063 \\
\hline 36 & 93,033 & 53 & 85,693 & 70 & 65,251 \\
\hline 37 & 92,777 & 54 & 84,979 & 71 & 63,335 \\
\hline 38 & 92,508 & 55 & 84,216 & 72 & 61,318 \\
\hline 39 & 92,223 & 56 & 83,399 & 73 & 59,202 \\
\hline 40 & 91,921 & 57 & 82,527 & 74 & 56,989 \\
\hline 41 & 91,601 & 58 & 81,598 & 75 & 54,684 \\
\hline 42 & 91,259 & 59 & 80,612 & 76 & 52,290 \\
\hline 43 & 90,895 & 60 & 79,569 & 77 & 49,815 \\
\hline 44 & 90,507 & 61 & 78,464 & 78 & 47,266 \\
\hline 45 & 90,094 & 62 & 77,294 & 79 & 44,649 \\
\hline & 89,651 & 63 & 76,058 & 80 & 41,849 \\
\hline
\end{tabular}

Source: IBGE (2006)

BBR, Braz. Bus. Rev. (Engl. ed., Online),

Vitória, v. 7, n. 1, Art. 4, p. 59-88, jan-apr.2010 


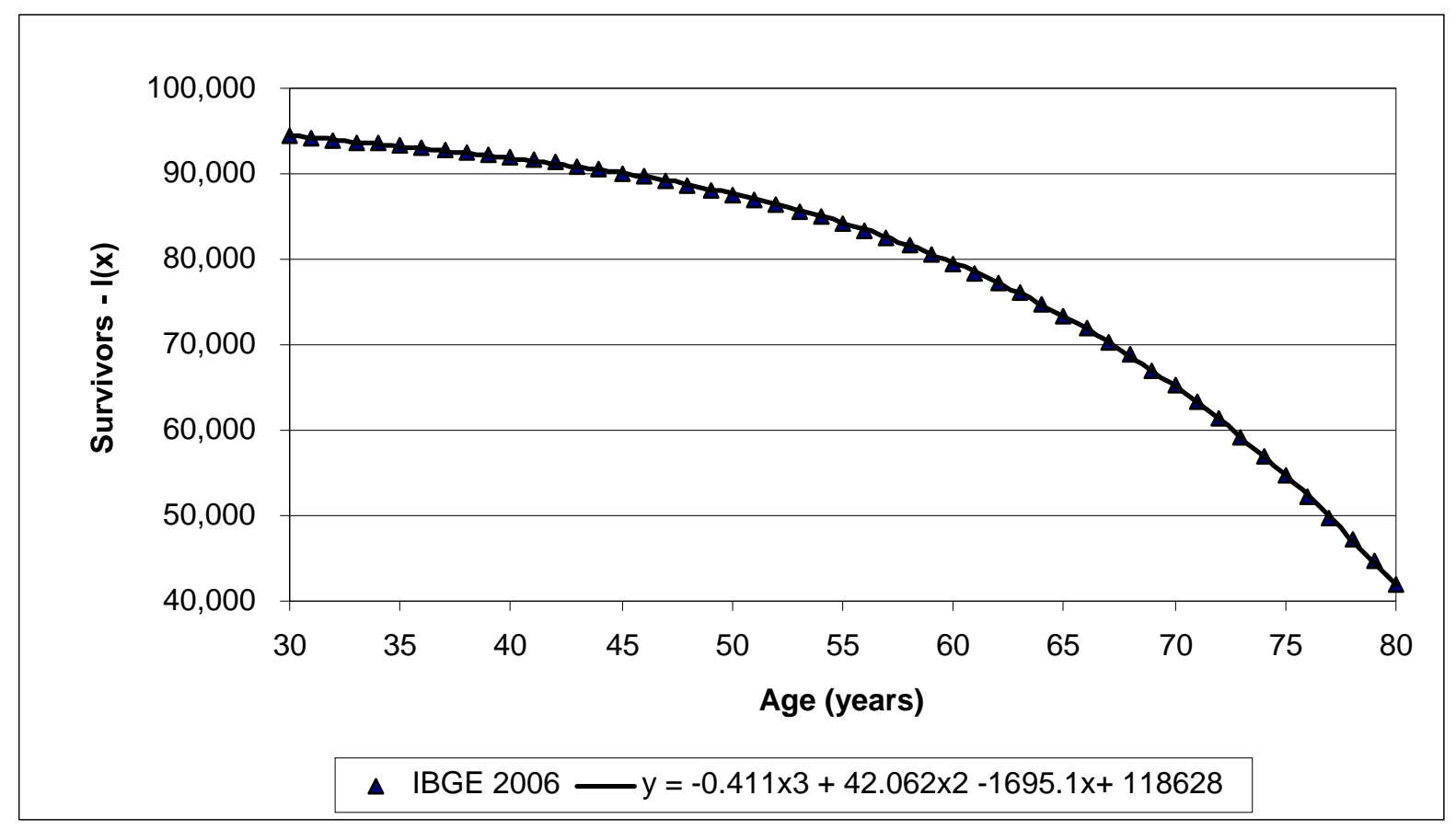

GRAPH 6: SURVIVORS TO AGE $X\left(L_{X}\right)$ - IBGE (2006) AND APPROXIMATION BY 3RDDEGREE POLYNOMIAL

Source: Authors' calculations

Table 11: Values of $l_{x}$ and ${ }_{t} P_{x}$ estimated according to the approximation presented in Graph 6

\begin{tabular}{|c|c|c|c|c|}
\hline Age $(X)$ & Correlate & $1(\mathrm{X})$ & $\mathrm{t}$ & $\mathrm{tPx}(\mathrm{x}=\mathrm{t}=0)$ \\
\hline 30.00 & 30 years & 94,538 & 0 & 100.0000 \\
\hline 30.08 & 30 years and 1 month & 94,515 & 1 & 99.9753 \\
\hline 30.17 & 30 years and 2 months & 94,492 & 2 & 99.9506 \\
\hline 30.25 & 30 years and 3 months & 94,468 & 3 & 99.9261 \\
\hline 30.33 & 30 years and 4 months & 94,445 & 4 & 99.9016 \\
\hline 30.42 & 30 years and 5 months & 94,422 & 5 & 99.8772 \\
\hline 30.50 & 30 years and 6 months & 94,399 & 6 & 99.8528 \\
\hline 30.58 & 30 years and 7 months & 94,376 & 7 & 99.8285 \\
\hline 30.67 & 30 years and 8 months & 94,353 & 8 & 99.8043 \\
\hline 30.75 & 30 years and 9 months & 94,330 & 9 & 99.7801 \\
\hline 30.83 & 30 years and 10 months & 94,308 & 10 & 99.7560 \\
\hline 30.92 & 30 years and 11 months & 94,285 & 11 & 99.7319 \\
\hline 31.00 & 31 years & 94,262 & 12 & 99.7079 \\
\hline 31.08 & 31 years and 1 month & 94,240 & 13 & 99.6840 \\
\hline 31.17 & 31 years and 2 months & 94,217 & 14 & 99.6601 \\
\hline 31.25 & 31 years and 3 months & 94,194 & 15 & 99.6363 \\
\hline 31.33 & 31 years and 4 months & 94,172 & 16 & 99.6125 \\
\hline 31.42 & 31 years and 5 months & 94,150 & 17 & 99.5888 \\
\hline
\end{tabular}




\begin{tabular}{|c|c|c|c|c|}
\hline 31.50 & 31 years and 6 months & 94,127 & 18 & 99.5651 \\
\hline 31.58 & 31 years and 7 months & 94,105 & 19 & 99.5415 \\
\hline 31.67 & 31 years and 8 months & 94,083 & 20 & 99.5179 \\
\hline 31.75 & 31 years and 9 months & 94,060 & 21 & 99.4944 \\
\hline 31.83 & 31 years and 10 months & 94,038 & 22 & 99.4709 \\
\hline 31.92 & 31 years and 11 months & 94,016 & 23 & 99.4474 \\
\hline 32.00 & 32 years & 93,994 & 24 & 99.4240 \\
\hline 32.08 & 32 years and 1 month & 93,972 & 25 & 99.4006 \\
\hline 32.17 & 32 years and 2 months & 93,950 & 26 & 99.3773 \\
\hline 32.25 & 32 years and 3 months & 93,928 & 27 & 99.3540 \\
\hline 32.33 & 32 years and 4 months & 93,906 & 28 & 99.3307 \\
\hline 32.42 & 32 years and 5 months & 93,884 & 29 & 99.3075 \\
\hline 32.50 & 32 years and 6 months & 93,862 & 30 & 99.2843 \\
\hline 32.58 & 32 years and 7 months & 93,840 & 31 & 99.2611 \\
\hline 32.67 & 32 years and 8 months & 93,818 & 32 & 99.2379 \\
\hline 32.75 & 32 years and 9 months & 93,796 & 33 & 99.2148 \\
\hline 32.83 & 32 years and 10 months & 93,774 & 34 & 99.1917 \\
\hline 32.92 & 32 years and 11 months & 93,752 & 35 & 99.1686 \\
\hline
\end{tabular}

Table 11 - Continued Values of $l_{x}$ and ${ }_{t} P_{x}$ estimated according to the approximation presented in Graph 6

\begin{tabular}{|c|c|c|c|c|}
\hline Age $(X)$ & Correlate & $1(\mathrm{X})$ & $\mathrm{n}$ & $\mathrm{tPx}(\mathrm{x}=\mathrm{t}=0)$ \\
\hline 33.00 & 33 years & 93,731 & 36 & 99.1456 \\
\hline 33.08 & 33 years and 1 month & 93,709 & 37 & 99.1226 \\
\hline 33.17 & 33 years and 2 months & 93,687 & 38 & 99.0995 \\
\hline 33.25 & 33 years and 3 months & 93,665 & 39 & 99.0765 \\
\hline 33.33 & 33 years and 4 months & 93,644 & 40 & 99.0536 \\
\hline 33.42 & 33 years and 5 months & 93,622 & 41 & 99.0306 \\
\hline 33.50 & 33 years and 6 months & 93,600 & 42 & 99.0076 \\
\hline 33.58 & 33 years and 7 months & 93,578 & 43 & 98.9847 \\
\hline 33.67 & 33 years and 8 months & 93,557 & 44 & 98.9618 \\
\hline 33.75 & 33 years and 9 months & 93,535 & 45 & 98.9388 \\
\hline
\end{tabular}




\begin{tabular}{|c|c|c|c|c|}
\hline 33.83 & 33 years and 10 months & 93,513 & 46 & 98.9159 \\
\hline 33.92 & 33 years and 11 months & 93,492 & 47 & 98.8930 \\
\hline 34.00 & 34 years & 93,470 & 48 & 98.8701 \\
\hline 34.08 & 34 years and 1 month & 93,448 & 49 & 98.8472 \\
\hline 34.17 & 34 years and 2 months & 93,427 & 50 & 98.8243 \\
\hline 34.25 & 34 years and 3 months & 93,405 & 51 & 98.8014 \\
\hline 34.33 & 34 years and 4 months & 93,383 & 52 & 98.7785 \\
\hline 34.42 & 34 years and 5 months & 93,362 & 53 & 98.7555 \\
\hline 34.50 & 34 years and 6 months & 93,340 & 54 & 98.7326 \\
\hline 34.58 & 34 years and 7 months & 93,318 & 55 & 98.7097 \\
\hline 34.67 & 34 years and 8 months & 93,297 & 56 & 98.6868 \\
\hline 34.75 & 34 years and 9 months & 93,275 & 57 & 98.6638 \\
\hline 34.83 & 34 years and 10 months & 93,253 & 58 & 98.6409 \\
\hline 34.92 & 34 years and 11 months & 93,232 & 59 & 98.6179 \\
\hline 35.00 & 35 years & 93,210 & 60 & 98.5949 \\
\hline
\end{tabular}

Source: Authors' calculations

' The expression Free Credit refers to the non-directed credit of the financial system, except with financial intermediaries. GDP is estimated by the Central Bank for 12 months at prices of the indicated month, using data from the IBGE, deflated by the centered IGP-DI (general market price index). Fixed interest is the average rate (fixed in advance) charged on credit transactions with non-directed resources at the referential interest rate (the weighted average rate calculated by the Central Bank from a sample of most financial institutions). Analogously, the fixed spread is the average spread charged on credit transactions with free resources at the referential rate (fixed in advance). ${ }^{\text {ii }}$ The numbers refer to loans regulated by BCB Circular 2957 of December 30, 1999. The data are expressed in constant values of May 2008, updated by us according to the consumer price index (IPCA). ${ }^{\text {iii }}$ The fact that many banks only managed to conclude agreements with the INSS for transfer of the deductions at the end of October 2004 can perhaps explain this acceleration. ${ }^{\text {iv }}$ The balances in the graph were updated by the consumer price index (IPCA) accumulated through December 2007. ${ }^{\mathrm{v}}$ PIS is the Contribution to the Social Integration Fund, COFINS is the Contribution to Finance Social Security, IOF is the Tax on Financial Transactions, IR is Income Tax and CSLL is Social Contribution on Net Profits. "Contributions" are taxes whose revenues are earmarked for specific purposes instead of going into the general fund. In January 2008, when the CPMF (a 
provisional levy of $0.38 \%$ on checks and other financial transfers) was not extended by the Senate, the government, to counteract the loss of revenue, increased the CSLL rate for financial institutions from 9\% to $15 \%$ and established IOF of $0.38 \%$ of the loan value. ${ }^{\text {vi }}$ The authors found a positive empirical relationship between the level of credit and growth of per capita GDP.

vii According to Rodrigues et al. (2006), payroll loans is an important factor in the reduction of the rates charged on personal loans. In turn, Barros, Fagundes \& Cavalcante (2007) concluded that the persistence of high interest rates on payroll loans is due to the high administrative costs, mainly derived from payment of commissions to correspondent banks. viii On April 30, 2008, banks were forbidden to charge loan origination fees on any type of loan, according to National Monetary Council Resolution 3518/07. ${ }^{\text {ix }}$ The names of the financial institutions have been omitted. Note that the numbering in Tables 5, 7 and 8 is mutually consistent. ${ }^{\mathrm{x}}$ The deduction from the equation to calculate the installments for a fully amortized loan can be found in any basic financial mathematics book, such as Bruni \& Fama (2002). ${ }^{\mathrm{xi}}$ The result of this equation does not completely reflect the installments the borrower actually pays, because it does not include the IOF (tax on financial operations). However, the absence of the IOF does not distort the final results because it represents a cost to the borrower, not to the bank, so it does not affect the bank's rate of return.

xii The social security benefits is defined by a "social security factor", which consider the age and life expectancy of the beneficiary. ${ }^{\text {xiii }}$ Such a high $R^{2}$ value is evidence of the existence of high multicollinearity of the explanatory variables. However, as pointed out by Wooldridge (2003, Ch. 3), multicollinearity is not such a serious problem, since it does not violate any of the assumptions of the OLS model, particularly that the estimators are not biased. ${ }^{\text {xiv }}$ The latest date disclosed by Dataprev resulted in an average term of 31 months, but this precedes the extension of the maximum term to 60 months. For this reason, we decided to simulate data for terms of 36 and 60 months, also considering that some financial institutions charge different interest rates for different loan periods.

BBR, Braz. Bus. Rev. (Engl. ed., Online), 